\title{
MATERIAL CLASSIFICATION BASED ON VIBRATION ANALYSIS
}

\section{REZGÉSELEMZÉS ALAPÚ ANYAGVIZSGÁLAT}

\author{
Mahmod Al-Bkree \\ Óbuda University, Bánki Donát Faculty of Mechanical and Safety Engineering, \\ Institute of Mechatronics and Vehicle Engineering. H-1081, Hungary, Budapest, \\ Népszínház u, 8; Phone: (+36-1) 666-5349, Fax: (+36-1) 666-5485, \\ albkri@stud.uni-obuda.hu
}

\begin{abstract}
In this paper we investigate the rule of object's vibration in identifying its material of construction. A simple vibration test is performed to classify different types of materials. The test is done by performing small hammer excitation on the object then records its vibration using one acceleration sensor. Four different materials were tested (steel, hardwood, softwood, and plastic). The vibration signal was analyzed using MATLAB based model. The trained model was able to recognize the testing samples of each material. The advantages of this method are that it is accurate, fast and simple and it could be performed on-site as well as it is relatively inexpensive.
\end{abstract}

Keywords: vibration analysis, material identification, real-time recognition, acceleration sensors, impact hammer.

\section{Összefoglalás}

Ebben a tanulmányban különböző anyagú tárgyak, mint objektumok, anyagszerkezeti felépítését vizsgáljuk rezgéstani vizsgálatokkal. Egyszerú rezgésvizsgálatokat végzünk a különböző típusú anyagok osztályozására. A vizsgálatokat egy rezgésgerjesztő kalapáccsal végezzük az anyagokon, majd rögzítjük a próbaanyag rezgéseit egy gyorsulásérzékelővel. Négy különböző anyagot vizsgáltunk: acél, keményfa, puhafa és műanyag. A rezgésjelet MATLAB alapú modell segítségével elemezzük. A kifejlesztett modell képes volt felismerni az egyes anyagok vizsgálati mintáit. Ennek a módszernek az előnye, hogy aránylag pontos, gyors és egyszerü, helyszíni kivitelezéssel elvégezhető és nem utolsó sorban viszonylag olcsónak tekinthetö.

Kulcsszavak: vibrációs analízis, anyag meghatározás, valós idejü felismerés, gyorsulási szenzor, rezgető kalapács.

\section{Introduction}

Material classification has many industrial and commercial applications, As well as in real-time recognition for the selfautonomous machines and robots. The proposed testing method is using small hammer which could easily be attached to a robotic arm to provide it with real-time recognition of surrounding materials.
The field of non-destructive testing (NDT) of materials is a wide area, including any technique that extracts information about the condition of a material specimen without altering its physical and/or chemical properties (see, e.g., [1] for a survey of different NDT methods). 


\subsection{The experiment setup}

An acceleration sensor (Type SCA610) has been attached to a hammer, the sensor output signal is connected to the computer through data aquisition unit (DAQ) and MATLAB software is used to record the signal and process it and provide recognition as shown in the following figure 1.

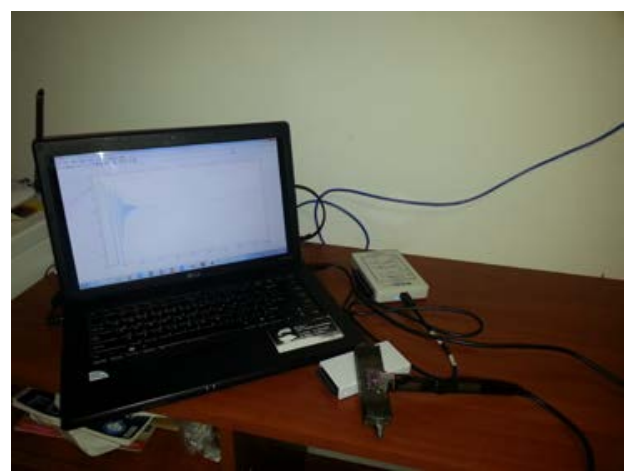

(A)

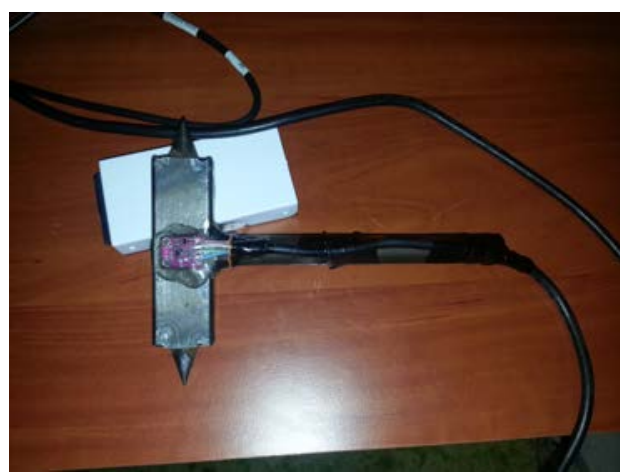

(B)

Figure 1. (A) a photo showing the connection Hammer to (DAQ) to the laptop. (B) is showing the sensor attached to the Hammer.

\subsection{Measurement}

4 objects with different material were tested, 5 vibrations recorded for each, the vibration waveform produced by an impact is a transient (short duration) energy transfer event. The spectrum is continuous, with a maximum amplitude at $0 \mathrm{~Hz}$ and decaying amplitude with increasing frequency. Figures 2.

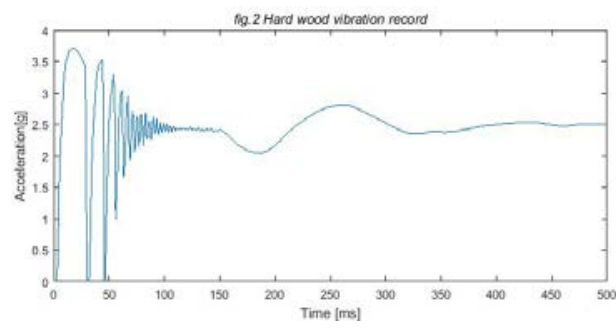

Figure 2. the vibration signal of Hardwood.

\subsection{The Signal Processing}

For analysis each vibration signal was sampled, the sampling frequency $(\mathrm{Fs})=1$ $\mathrm{kHz}$, and the cutoff frequency of the accelerometer integrated circuit is about 70 Hz.

The signal is impulse in nature and while Fast Fourier Transform is an industry standard to process the signal sequences, we have decided to perform a similar estimation of Welch Power Spectral Density (WPSD) together with Histogram, see Figure 3, also the Mean and the standard deviation values were calculated for each signal.

4 processed signals of each material are used to train the machine learning algorithms on MATLAB Classification Learner Model. and the fifth record was used to test the recognition after the training.

\subsection{Machine Learning}

The MATLAB Classification Learner app was used to train our model to classify the processed vibration data. The automated training models are compared to find the best classification model type, including decision trees, discriminant analysis, support vector machines, logistic regression, nearest neighbors, and Gaussian kernel classification. 

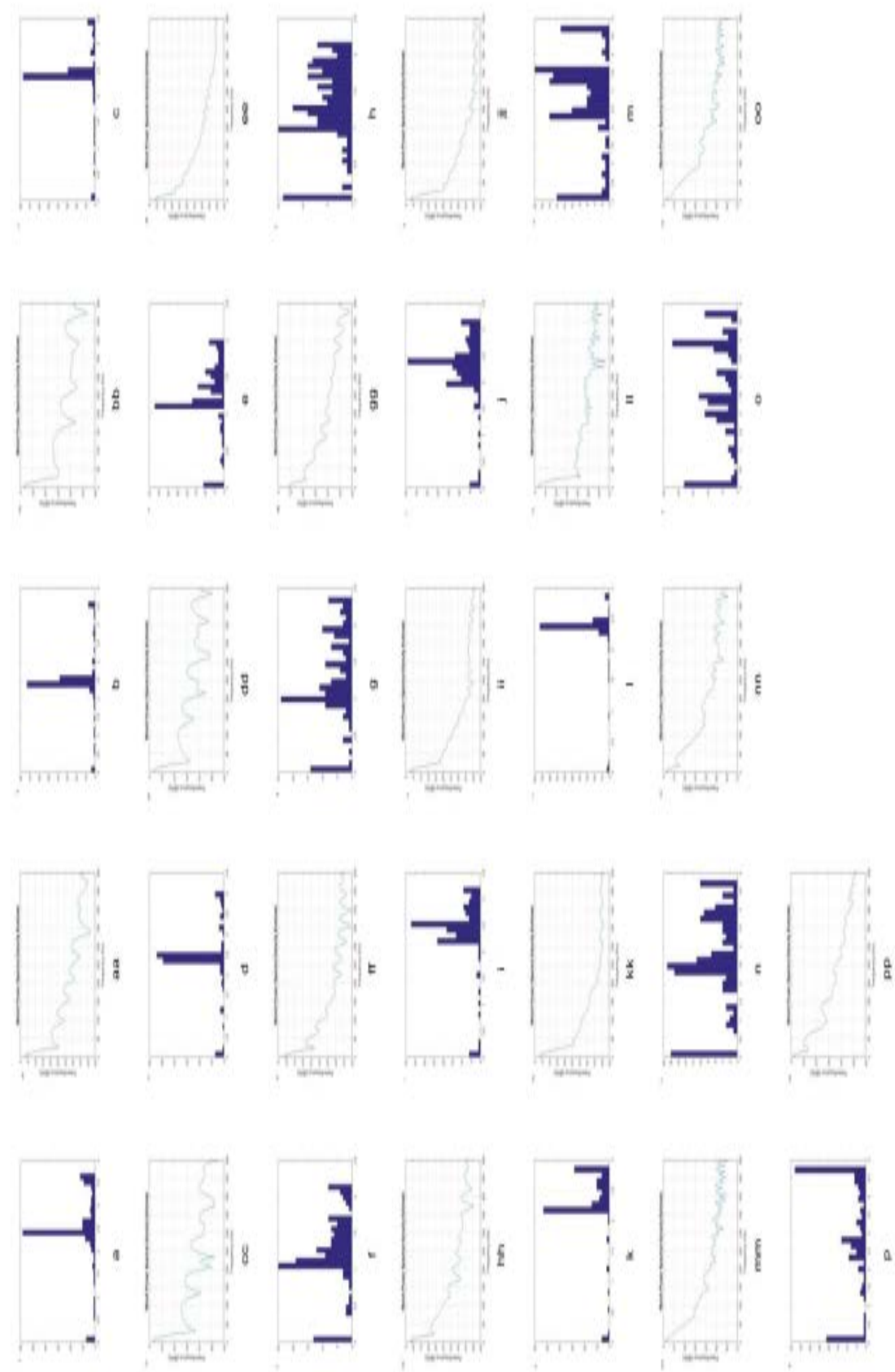

Figure 3. Histogram and (WPSD) graphs for the total 16 signals that used for training the MATLAB Classifier. 


\subsection{Result and Discussion}

The classifier identified the different pattern of the processed signals, and a scatter representation was produced as shown in Figure 4.

The hardwood and the steel signals were near of overlapping, which suggests that more signal processing is needed.

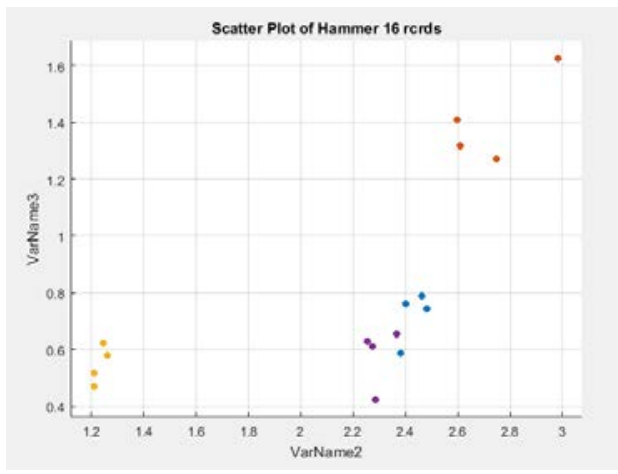

Figure 4. Scatter plot from MATLAB Classifier showing the four Materials in colors, softwood in yellow, hardwood in purple, steel in blue, and plastic in red.

The derivatives of the first peak was suggested to be performed to have more distinguished results, some other signal processing tools (see [2-8]) could enhance the result.

\section{Conclusions}

This experiment is a part of ongoing project and it is used to proof the concept. Classifying different material based on their vibration signal analysis using tools on MATLAB could be useful in many applications.

The vibration test is fast and portable and not expensive.
A larger dataset is needed to determine the accuracy, and an expanded set of material to be investigated in future work.

MATLAB is a powerful tool and its machine learning algorithms could be used in any data analysis project to classify different patterns.

\section{References}

[1] Hola J., Bien J., Sadowski L., Schabowicz K. Non-destructive and semi-destructive diagnostics of concrete structures in assessment of their durability. Bull. Pol. Acad. Sci. Tech. Sci. 2015;63:87-96.

[2] M. Al Janaideh, P. Krejčí: Inverse RateDependent Prandtl-Ishlinskii Model for Feedforward Compensation of Hysteresis in a Piezomicropositioning Actuator, IEEE/ASME Transactions on Mechatronics, Vol. 18, Number 5, 2013.

[3] W. Zhenyan, Z. Zhen, Z. Kemin: Precision Tracking Control of Piezoelectric Actuator using a Hammerstein-based Dynamic Hysteresis Model, 35th IEEE Chinese Control Conference, 27-29, China, 2016.

[4] Y. P. A. Yong, N. J. Hurley , G. C. M. Silvestre: Single-trial EEG classification for brain-computer interface using wavelet decomposition. Dept. of Computer Science, University College Dublin.

[5] V. N. Shahid, N. Perraudin, V. Kalofolias, G. Puy, P. Vandergheynst: Fast robust PCA on graphs. IEEE Journal of Selected Topics in Signal Processing, vol. 10, no. 4, pp. $740-$ 756, 2016.

[6] V. Kalofolias, How to learn a graph from smooth signals. In: International Conference on Artificial Intelligence and Statistics AISTATS, Cadiz, Spain, vol. 13, 2016.

[7] C. Zhang, D. Florêncio, P. A. Chou: Graph signal processing- a probabilistic framework. Microsoft Res., Redmond, WA, USA, Tech. Rep. MSR-TR-2015-31, 2015.

[8] Le Fur Y, Cozzone P J.: FID modulus: $a$ simple and efficient technique to phase and align MR spectra. MAGMA 2014; 27:131148. 